\title{
Pengaruh Gaya Belajar Terhadap Prestasi Belajar Mahasiswa Program Studi Pendidikan Matematika (IAIM NU) Metro
}

\author{
Santi Widyawati \\ IAIM NU Metro, fredigpsw@gmail.com
}

Submitted : 10-04-2016, Revised : 19-05-2016, Accepted : 16-06-2016

\begin{abstract}
Learning style is one of the factors that allegedly affect the learning achievement (GPA) of Mathematics Education Mathematics Program of Maarif Nahdatul Ulama Institute of Islamic Studies. The purpose of this research is to know "whether there is influence of learning style type (Visual, Auditorial, and kinestetik) to student learning achievement of Mathematics Education Program of Maarif Nahdatul Ulama Islamic Institute of Mathematics". The type of this research is comparative causal research with $3 \times 1$ research design. The population in this research is all students of semester IV of Mathematics Education program of Maarif Islamic Institute Nahdatul Ulama Metro academic year 2015/2016. The sample in this study was obtained by using class random technique. The sample in this study consists of 22 students with details of 10 students who have visual learning style, 4 students who have auditorial learning style, and 8 students who have kinesthetic learning style. Instruments used to collect data are questionnaire learning style and transcript of student grades semester IV of Mathematics Education Mathematics course Maarif Nahdatul Ulama Institute of Islamic Studies. Hypothesis testing in this study used a one way variance analysis with unequal cells. The result of this research is the influence of learning style to learning achievement (GPA) of Mathematics Education Mathematics Program of Maarif Nahdatul Ulama Institute of Islamic Studies. Furthermore, after further test using Scheefe 'method, it was found that students with visual learning styles had the same learning achievement with students with auditorial learning style, while both types of learning styles had better learning achievement compared with students with kinesthetic learning style.
\end{abstract}

Keyword:Achievement (GPA); Learning; Style

\begin{abstract}
Abstrak
Gaya belajar merupakan salah satu faktor yang diduga mempengaruhi prestasi belajar (IPK) mahasiswa program studi Pendidikan Matematika Institut Agama Islam Maarif Nahdatul Ulama Metro. Tujuan dari penelitian ini adalah untuk mengetahui "apakah terdapat pengaruh tipe gaya belajar (Visual, Auditorial, dan kinestetik) terhadap prestasi belajar mahasiswa program studi Pendidikan Matematika Institut Agama Islam Maarif Nahdatul Ulama Metro."

Jenis penelitian ini adalah penelitian kausal komparatif dengan desain penelitian $3 \times 1$. Populasi pada penelitian ini adalah seluruh mahasiswa semester IV program studi Pendidikan Matematika Institut Agama Islam Maarif Nahdatul Ulama Metro Tahun ajaran 2015/2016. Sampel dalam penelitian ini diperoleh dengan menggunakan teknik acak kelas. Sampel dalam penelitian ini terdiri atas 22 peserta didik dengan rincian 10 mahasiswa yang memiliki gaya belajar visual, 4 mahasiswa yang memiliki gaya belajar auditorial, dan 8
\end{abstract}


mahasiswa yang memiliki gaya belajar kinestetik. Instrumen yang digunakan untuk mengumpulkan data adalah angket gaya belajar dan transkip nilai mahasiswa semester IV program studi Pendidikan Matematika Institut Agama Islam Maarif Nahdatul Ulama Metro. Pengujian hipotesis pada penelitian ini menggunakan analisis variansi satu jalan dengan sel tak sama.

Hasil penelitian ini adalah terdapat pengaruh gaya belajar terhadap prestasi belajar (IPK) mahasiswa program studi Pendidikan Matematika Institut Agama Islam Maarif Nahdatul Ulama Metro. Lebih lanjut setelah dilakukan uji lanjut menggunakan metode Scheefe' diperoleh temuan bahwa mahasiswa dengan gaya belajar visual memiliki prestasi belajar yang sama dengan mahasiswa dengan gaya belajar auditorial, sedangkan kedua tipe gaya belajar tersebut memiliki prestasi belajar yang lebih baik dibandingkan dengan mahasiswa dengan gaya belajar kinestetik.

Kata Kunci: Gaya Belajar, Prestasi belajar (IPK)

\section{PENDAHULUAN}

Pendidikan merupakan usaha sadar untuk menyiapkan peserta didik melalui kegiatan bimbingan, pengajaran, dan latihan bagi peranannya di masa yang akan datang. Sekolah sebagai suatu pendidikan formal, secara sistematis merencanakan bermacam-macam lingkungan, yakni lingkungan pendidikan yang menyediakan berbagai kesempatan bagi peserta didik untuk melakukan berbagai kegiatan belajar. Dengan berbagai kesempatan belajar itu, pertumbuhan dan perkembangan peserta didik diarahkan dan didorong kearah pencapaian tujuan yang dicita-citakan. Lingkungan tersebut disusun dan ditata dalam suatu kurikulum, yang pada gilirannya dilaksanakan dalam bentuk proses pembelajaran (Hamalik, 2014). Dalam Undang-Undang Nomor 20 tahun 2003 tentang Sistem Pendidikan Nasional, Bab 1 Pasal 1 ayat (1) dikemukakan bahwa pendidikan adalah usaha sadar dan terencana untuk mewujudkan suasana belajar dan proses pembelajaran agar peserta didik secara aktif mengembangkan potensi dirinya untuk memiliki kekuatan spiritual, keagamaan, pengendalian diri, kepribadian, kecerdasan, akhlak mulia, serta keterampilan yang diperlukan dirinya, masyarakat, bangsa, dan Negara (Arifin, 2009: 39).

Dunia pendidikan tidak terlepas dari pembelajaran, karena pembelajaran merupakan proses membuat seseorang yang belum tahu menjadi tahu akan suatu permasalahan. Pembelajaran itu sendiri juga sudah sangat ditekankan oleh Allah dalam firmannya dalam surat Al-Alaq ayat 1-5 yang berbunyi:

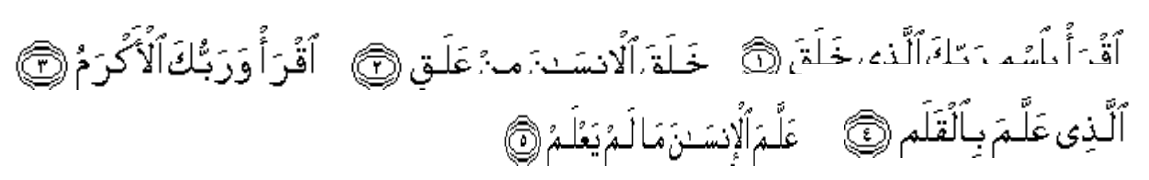

Artinya : Bacalah dengan (menyebut) nama Tuhanmu yang Menciptakan, Dia

telah menciptakan manusia dari segumpal darah. Bacalah, dan Tuhanmulah yang Maha pemurah, Yang mengajar (manusia) dengan perantaran kalam, Dia mengajar kepada manusia apa yang tidak diketahuinya. (Departemen Agama RI, 2004:904)

Berdasarkan beberapa ayat di atas sudah terlihat jelas bahwa Allah memberikan pengajaran bagi manusia untuk mengetahui apa yang tidak diketahui sebelumnya. 
Kemajuan dalam dunia pendidikan saat ini sudah sangat pesat, apalagi ditambah dengan kemajuan teknologi yang semakin canggih. Pendidikan menjadisalah satu modal penting untukmemajukan sebuah bangsa karena kesejahteraan dan kemajuan sebuah bangsa dapat dilihat dari tingkat pendidikannya.Salah satu komponen yang paling penting dari sistem pendidikan adalahkurikulum. Kurikulum Tingkat Satuan Pendidikan (KTSP) merupakan paradigmabaru dalam dunia pendidikan Indonesia yang diharapkan akan membawa perbaikan di dunia pendidikan. Dalam KTSP, belajar merupakan kegiatan aktif siswa dalam membangun makna atau pemahaman terhadap suatu konsep, sehingga dalam proses pembelajaran siswa merupakan sentral kegiatan atau pelaku utama sedangkan guru hanya menciptakan suasana yang dapat mendorong timbulnya motivasi belajar pada siswa. Reorientasi pembelajaran tidak hanya sebatas istilah teaching menjadi learning namunharussampai pada operasional pelaksanaan pembelajaran.

Matematika merupakan ilmu yang banyak dibutuhkan dalam kehidupan sehari-hari. Matematika juga menjadi sumber untuk pengembangan ilmu pengetahuan lain.Matematika mempunyai daya abstraksi yang mampu mengabstraksikan permasalahan-permasalahan yang sering muncul baik dalam matematika itu sendiri maupun dalam kehidupan sehari-hari sehingga mampu menyelesaikan permasalahan-permasalahan dengan tepat dan cepat.

Dalam pembelajaran matematika, seorang guru harus kreatif dan inovatif dalam memilih model pembelajaran yang sesuai dengan materi yang diajarkan.Diperlukan suatu model pembelajaran yang bisa membuat pembelajaran menjadi pengalaman yang nyata atau real, sehingga pemahaman konsep matematika dimungkinkan bisa lebih mudah diterima siswa. Contoh-contoh yang diberikan guru hendaknya sedekat mungkin dengan dunia nyata, sehingga siswa memahami keterkaitan antara materi pelajaran dengan permasalahan yang ada di dalam kehidupan sehari-hari.

Matematika merupakan salah satu materi yang wajib diketahui oleh para peserta didik, karena matematika merupakan ilmu yang memiliki peran penting bagi kehidupan manusia. Banyak kegiatan manusia dalam kehidupan sehari-hari yang tidak terlepas dari peranan matematika, seperti proses jual beli, pembangunan gedung dan lain-lain. Matematika merupakan ilmu universal yang mendasari perkembangan teknologi modern, memajukan daya pikir manusia, dan mempunyai peran penting dalam berbagai disiplin ilmu (Yulianti dkk, 2010: 25). Perkembangan pada bidang teknologi informasi dan komunikasi dewasa ini dilandasi oleh perkembangan matematika, sehingga untuk menguasai dan menciptakan teknologi dimasa yang akan datang diperlukan penguasaan matematika yang kuat sejak dini. Dalam dunia pendidikan, setiap individu akan mengalami proses belajar yang bertujuan untuk meningkatkan kualitas diri. Oleh karena itu, matematika menjadi salah satu mata pelajaran yang diterapkan diberbagai tingkat pendidikan, mulai dari Sekolah Dasar (SD), Sekolah Menengah Pertama (SMP), Sekolah Menengah Atas (SMA), sampai pada tingkat perguruan tinggi.

Pandangan masyarakat tentang pelajaran matematika merupakan pelajaran yang sulit dan menakutkan adalah hal yang cukup beralasan. (Marpaung, 2003) mengungkapkan "pendidikan matematika kita selama ini tidak berhasil meningkatkan pemahaman matematika yang baik pada siswa, tetapi berhasil menumbuhkan perasaan takut, persepsi terhadap matematika sebagai ilmu yang sukar dikuasai, tidak bermakna, membosankan, menyebabkan stres pada diri siswa." Ungkapan tersebut mengindikasikan bahwa bagi sebagian besar siswa, pembelajaran matematika selama ini belum mampu mengubah ranah afektif dan kognitif siswa menuju yang lebih baik. 
Matematika memiliki peran yang sangat penting dalam membangun kemampuan berpikir logis, sistematis, dan analitis. Sehingga tidaklah mengherankan jika kedudukan matematika dalam cabang ilmu pengetahuan berada pada posisi yang tinggi, karena matematika akan mendasari kemampuan pemahaman atau berpikir seorang siswa pada mata pelajaran yang lain. Beberapa pakar matematika menyebutkan matematika sebagai "ratu" dari segala ilmu pengetahuan (Tarmidi, 2006), karena tidak dapat dipungkiri matematika sangat lekat dan selalu muncul dalam setiap aktifitas kehidupan manusia. Oleh karenanya harapan yang kemudian muncul dari para pendidik dan orang tua adalah penguasaan yang baik pada konsep-konsep matematika oleh siswa.

Sejalan dengan paradigma baru pendidikan di Indonesia yang lebih menekankan pada peserta didik sebagai manusia yang memiliki potensi untuk belajar dan berkembang, pemerintah mendorong pelaksanaan pembelajaran pada jenjang pendidikan dasar dan menengah yang berorientasi pada Pembelajaran Aktif Kreatif Efektif dan Menyenangkan (PAKEM). (Depdiknas, 2005) menyatakan pembelajaran yang berorientasi pada PAKEM adalah pembelajaran yang dirancang agar mengaktifkan anak mengembangkan kreatifitas sehingga efektif namun tetap menyenangkan.

Salah satu perguruan tinggi yang memiliki program studi yang mengajarkan tentang matematika adalah Institut Agama Islam Maarif Nahdatul Ulama (IAIM NU) Metro yang diberi nama Program Studi Pendidikan Matematika. Salah satu tujuan diadakannya program studi ini adalah untuk mencetak calon guru matematika yang profesional dan berakhlak mulia. Untuk mencapai tujuan tersebut, pembelajaran di kelas harus memperhatikan berbagai macam faktor yang mempengaruhi prestasi belajar mahasiswa. Prestasi belajar mahasiswa dalam penelitian ini tampak pada indeks prestasi komulatif (IPK) yang mahasiswa miliki.

Salah satu faktor belajar yang diduga berpengaruh dalam pencapaian prestasi belajar mahasiswa adalah gaya belajar. Hal ini berdasarkan penelitian yang telah dilakukan oleh (Putra, Atmojo, \& Sujadi, 2014) dan (Ramlah, 2014) yang memberikan hasil bahwa kecenderungan gaya belajar yang dimiliki peserta didik memberikan pengaruh yang berbeda pada prestasi belajarnya.

Handayani (dalam Ramlah, 2014: 68) mengungkapkan bahwa salah satu cara yang dapat dilakukan orang tua agar anaknya memiliki prestasi yang baik adalah dengan menemukan gaya belajar anak dan menerima anak sesuai dengan kemampuan yang dimiliki. Secara teori, ada dua kategori tentang bagaimana individu belajar. Pertama, adalah cara individu dapat menyerap informasi dengan mudah, konsep ini disebut modalitas belajar. Kedua adalah bagaimana cara individu mengatur dan mengelola informasi tersebut, konsep ini disebut dominasi otak. Gaya belajar merupakan cara seseorang untuk menyerap, mengatur dan mengolah bahan informasi atau bahan pelajaran yang telah diterima selama pembelajaran. Berdasarkan pada hal tersebut, diduga kecenderungan gaya belajar yang dimiliki masing-masing mahasiswa juga berpengaruh terhadap prestasi belajarnya. Agar dapat memahami materi yang dipelajari secara maksimal, tentunya seorang dosen harus mengetahui gaya belajar yang dimiliki oleh masing-masing mahasiswanya.

Gaya belajar memiliki peranan sangat penting dalam setiap pembelajaran, salah satunya adalah pembelajaran matematika, karena gaya belajar matematika merupakan ciri khas konsisten yang dilakukan mahasiswa dalam menyerap suatu informasi. Gaya belajar berdasarkan modalitas menurut Grinder (De Porter \& M., 2004) dapat digolongkan menjadi tiga macam, yaitu gaya belajar visual (lebih peka terhadap indera penglihatan), gaya belajar auditorial (lebih peka terhadap indera pendengaran), dan gaya belajar kines tetik (lebih peka 
dengan bergerak, bekerja, dan menyentuh). Walaupun ketiga modalitas gaya belajar ini ada dalam diri seorang mahasiswa, kebanyakan masing-masing mahasiswa memiliki kecenderungan pada salah satu diantara ketiganya (De Porter \& Hernacki, 1999). Dari beberapa keterangan di atas, penulis merasa tertarik melakukan penelitian yang berjudul "Pengaruh Gaya Belajar terhadap Prestasi Belajar (IPK) Mahasiswa Prodi Pendidikan Matematika Institut Agama Islam Maarif NU Metro Tahun Ajaran 2015/2016".

\section{METODE PENELITIAN}

Penelitian ini termasuk penelitian kausal komparatif yang dirancang dengan desain faktorial $3 \times 1$. Populasi pada penelitian ini adalah seluruh mahasiswa semester IV program studi pendidikan matematika IAIM NU Maarif Metro tahun ajaran 2015/2016. Sampel penelitian sebanyak 22 responden yang terdiri dari 10 mahasiswa dengan gaya belajar visual, 4 mahasiswa dengan gaya belajar auditorial, dan 8 mahasiswa dengan gaya belajar kinestetik.

Variabel dalam penelitian ini terbagi menjadi dua, yaitu variabel terikat dan variabel bebas. Variabel terikat dalam penelitian ini adalah prestasi belajar matematika mahasiswa program studi pendidikan matematika yang dilihat dari Indeks Prestasi Komulatif (IPK) yang mahasiswa miliki, sedangkan variabel bebas dalam peneletian ini adalah gaya belajar (visual, auditorial, dan kinestetik). Teknik pengumpulan data menggunakan metode dokumentasi dan metode angket. Metode dokumentasi digunakan untuk mengumpulkan transkip nilai mahasiswa yang didalamnya termuat data IPK mahasiswa, sedangkan metode angket digunakan untuk melihat kecenderungan gaya belajar yang dimiliki masing-masing mahasiswa. Dalam penelitian ini, jenis angket yang akan digunakan adalah angket langsung dan menggunakan skala Likert. Disebut angket langsung karena peneliti langsung menyampaikan angket tersebut kepada subjek penelitian (Budiyono, 2003).

Instrumen dalam penelitian ini adalah angket gaya belajar. Instrumen angket gaya belajar ini telah diuji coba sebelumnya oleh peneliti, sehingga di dalam penelitian ini peneliti tidak lagi melakukan uji coba terhadap angket tersebut dan langsung menggunakannya.

\section{HASIL PENELITIAN DAN PEMBAHASAN}

Hasil uji prasyarat pada data prestasi belajar(IPK) menyimpulkan bahwa semua sampel berasal dari populasi yang berdistribusi normal. Hal ini ditunjukkan pada perhitungan uji normalitas pada data prestasi belajar. Rangkuman uji normalitas disajikan pada tabel berikut:

Tabel 1. Rangkuman Uji Normalitas (Liliefors)

\begin{tabular}{lccccc}
\hline $\begin{array}{c}\text { Gaya } \\
\text { Belajar }\end{array}$ & $\mathbf{N}$ & Lobs & Ltabel & Keputusan & Kesimpulan \\
\hline Visual & 10 & 0,209 & 0,258 & $\begin{array}{c}H_{0} \\
\text { diterima }\end{array}$ & Normal \\
\hline Auditorial & 4 & 0,149 & 0,381 & $\begin{array}{c}H_{0} \\
\text { diterima }\end{array}$ & Normal \\
\hline Kinestetik & 8 & 0,280 & 0,285 & $\begin{array}{c}H_{0} \\
\text { diterima }\end{array}$ & Normal \\
\hline
\end{tabular}


Berdasarkan tabel 1. di atas, untuk masing-masing kelompok gaya belajar, nilai Lobs lebih dari $L_{0,05 ; 2}$ sehingga $H_{0}$ diterima. Hal ini berarti bahwa masing-masing kelompok sampel berasal dari populasi yang berdistribusi normal.

Hasil uji prasyarat pada data prestasi belajar (IPK) juga menyimpulkan bahwa ketiga kelompok sampel memiliki variansi yang sama (homogen). Hal ini ditunjukkan pada perhitungan uji homogenitas pada data prestasi belajar (IPK) mahasiswa. Rangkuman uji homogenitas disajikan pada tabel berikut:

Tabel 2. Rangkuman Uji Homogenitas

\begin{tabular}{rccccc}
\hline Sampel & $\boldsymbol{K}$ & $\chi_{\text {obs }}^{2}$ & $\chi_{0,05: 2}^{2}$ & Keputusan & Kesimpulan \\
\hline Gaya Belajar & 3 & 3,365 & 5,991 & $H_{0}$ diterima & Homogen \\
\hline
\end{tabular}

Berdasarkan tabel 2. di atas, diperoleh bahwa untuk sampel gaya belajar memiliki nilai $\chi_{\text {obs }}^{2}$ yang kurang dari $\chi_{0,05: 2}^{2}$ dan tidak terletak di daerah kritis sehingga $H_{0}$ untuk gaya belajar diterima. Hal ini berarti bahwa kelompok sampel mempunyai variansi yang homogen atau mempunyai variansi yang sama..

Selanjutnya, dilakukan uji analisis variansi satu jalan sel tak sama pada data prestasi belajar mahasiswa (IPK). Rangkuman uji analisis variansi satu jalan sel tak sama disajikan pada Tabel 1. berikut.

Tabel 3. Rangkuman Analisis Variansi Satu Jalan Sel tak Sama

\begin{tabular}{ccccccc}
\hline Sumber & JK & $\boldsymbol{d k}$ & $\mathbf{R K}$ & $\mathbf{F}_{\text {obs }}$ & $\mathbf{F}_{\text {tabel }}$ & Kesimpular \\
\hline Gaya belajar (A) & 0,1 & 2 & 0,04825 & 3,6187 & 3,52 & $H_{\text {OA ditolak }}$ \\
Galat & 0,25 & 19 & 0,0134 & & & \\
Total & 0,35 & 21 & & & & \\
\hline
\end{tabular}

Berdasarkan Tabel 3., dapat dilihat bahwa $F_{\text {obs }}$ lebih besar dari $F_{\text {tabel, }}$ ha i berarti ketiga tipe gaya belajar memberikan efek yang berbeda terhadap prestasi belajar matematika mahasiswa. Untuk melihat perbedaan-perbedaan yang signifikan dari ketiga tipe gaya belajar tersebut, perlu dilakukan uji lanjut pasca anava dengan menggunakan metode Scheffe'. Rangkuman rerata marginal data IPK mahasiswa disajikan pada Tabel 4. berikut:

Tabel 4. Rerata Marginal Gaya belajar

\begin{tabular}{lc}
\hline \multicolumn{1}{c}{ Gaya Belajar } & Rerata Marginal \\
\hline Visual & 3,4710 \\
\hline Auditorial & 3,4725 \\
\hline Kinestetik & 3,3338 \\
\hline
\end{tabular}

Pada perhitungan analisis variansi satu jalan dengan sel tak sama di atas bahwa $H_{0 A}$ ditolak, sehingga perlu dilakukan uji komparasi ganda antar baris. Rangkuman uji komparasi ganda antara baris disajikan dalam Tabel 5. berikut:

Tabel 5. Rangkuman Uji Komparasi Ganda antar Baris

\begin{tabular}{|c|c|c|c|c|}
\hline No. & $\mathrm{H}_{0}$ & Fhit & Ftabel & Keputusan Uji \\
\hline 1 & $\mu_{1 .}=\mu_{2}$ & 0,0005 & 3,52 & Diterima \\
\hline 2 & $\mu_{1}=\mu_{3_{a}}$ & 6,7177 & 3,52 & Ditolak \\
\hline 3 & $\mu_{2}=\mu_{3}$ & 4,1192 & 3,52 & Ditolak \\
\hline
\end{tabular}


Berdasarkan tabel 5. pada hipotesis nol yang pertama, dapat dilihat bahwa Fhit lebih

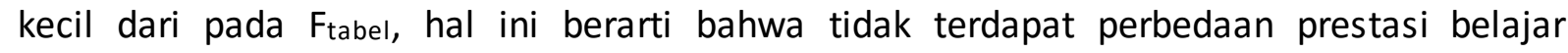
mahasiswa yang memiliki gaya belajar visual dan mahasiswa yang memiliki gaya belajar auditorial. Sehingga dapat disimpulkan bahwa mahasiswa dengan gaya belajar visual dan mahasiswa dengan gaya belajar auditorial mempunyai prestasi belajar yang sama.

Pada hipotesis nol yang kedua di tabel 5. dapat dilihat bahwa Fhit lebih besar dari $F_{\text {tabel, }}$ hal ini berarti bahwa terdapat perbedaan prestasi belajar mahasiswa yang memiliki gaya belajar visual dan mahasiswa yang memiliki gaya belajar kinestetik, sehingga dapat disimpulkan bahwa terdapat perbedaan prestasi belajar antara mahasiswa yang memiliki gaya belajar visual dan mahasiswa yang memiliki gaya belajar kinestetik. Berdasarkan tabel 4, dapat dilihat bahwa rerata marginal kelompok gaya belajar visual sebesar 3,4710 lebih besar dari rerata marginal mahasiswa yang memiliki gaya belajar kinestetik yaitu 3,3338, sehingga dapat disimpulkan bahwa prestasi belajar antara mahasiswa yang memiliki gaya belajar visual lebih baik dibandingkan dengan mahasiswa yang memiliki gaya belajar kinestetik.

Pada hipotesis nol yang ketiga di tabel 5. dapat dilihat bahwa Fhit lebih besar dari $F_{t a b e l,}$ hal ini berarti bahwa terdapat perbedaan prestasi belajar mahasiswa yang memiliki gaya belajar auditorial dan mahasiswa yang memiliki gaya belajar kinestetik, sehingga dapat disimpulkan bahwa terdapat perbedaan prestasi belajar antara mahasiswa yang memiliki gaya belajar auditorial dan mahasiswa yang memiliki gaya belajar kinestetik. Berdasarkan tabel 4, dapat dilihat bahwa rerata marginal kelompok gaya belajar auditorial sebesar 3,4725 lebih besar dari rerata marginal mahasiswa yang memiliki gaya belajar kinestetik yaitu 3,3338 , sehingga dapat disimpulkan bahwa prestasi belajar antara mahas iswa yang memiliki gaya belajar auditorial lebih baik dibandingkan dengan mahasiswa yang memiliki gaya belajar kinestetik.

Hasil penelitian ini memang telah diduga sebelumnya bahwa mahasiswa yang mempunyai gaya belajar visual dan auditorial akan lebih baik prestasi belajarnya dibandingkan mahasiswa dengan gaya belajar kinestetik dalam mempelajari dan memahami materi-materi yang terdaapat pada program studi pendidikan matematika Institut Agama Islam Maarif Nahdatul Ulama Metro. Hal ini disebabkan karena proses pembelajaran di kelas, dosen masih sering menggunakan proyektor sehingga anak dengan gaya belajar visual lebih tertarik dan dosen juga masih menggunakan metode ceramah dalam menyampaikan materinya sehingga mahasiswa dengan gaya belajar auditorial lebih terbantu dalam memahami materi kuliah. Kebiasaan dosen dalam mengajar tersebut dimungkinkan membuat anak dengan gaya belajar kinestetik tidak bisa belajar secara maksimal karena mahasiswa dengan gaya belajar kinestetik lebih menyukai belajar dengan cara praktik. Hasil penelitian ini juga sejalan dengan penelitian (Putra, Atmojo, \& Sujadi, 2014) dan (Ramlah, 2014) yang memberikan hasil bahwa kecenderungan gaya belajar yang dimiliki peserta didik memberikan pengaruh yang berbeda pada prestasi belajarnya.

\section{SIMPULAN DAN SARAN}

Berdasarkan hasil analisis data dan pembahasan yang telah dilakukan, maka dapat disimpulkan bahwa mahasiswa dengan gaya belajar visual memiliki prestasi belajar yang sama dengan mahasiswa dengan gaya belajar auditorial, sedangkan keduanya memiliki 
prestasi belajar yang lebih baik dibandingkan dengan mahasiswa dengan gaya belajar kinestetik.

Berdasarkan simpulan hasil penelitian di atas, penulis dapat memberikan beberapa saran hendaknya setiap dosen yang mengampu mata kuliah pada program studi pendidikan matematika Institut Agama Islam Maarif Nahdatul Ulama Metro lebih memperhatikan gaya belajar mahasiswa dikarenakan gaya belajar yang dimiliki mahasiswa tersebut berpengaruh dalam prestasi belajar, lebih khusus pada mahasiswa dengan gaya belajar kinestetik. Dosen lebih baik menggabungkan antara penggunaan proyektor, metode ceramah dan praktik disaat memberikan materi di kelas agar ketiga tipe mahasiswa dengan gaya belajar tersebut dapat terbantu dalam memahami materi yang disampaikan. Peneliti juga memberikan kesempatan kepada calon peneliti lain untuk melanjutkan penelitian yang telah peneliti lakukan, agar dapat bermanfaat bagi kemajuan kualitas pendidikan di Lampung khususnya pada program studi pendidikan matematika Institut Agama Islam Maarif Nahdatul Ulama Metro.

\section{DAFTAR PUSTAKA}

Arifin, Z. (2009). Evaluasi Pembelajaran. Bandung: PT Remaja Rosdakarya.

Budiyono. (2003). Metodologi Penelitian Pendidikan. Surakarta: UNS Press.

De Porter, B., \& Hernacki, M. (1999). Quantum Learning: Membiasakan Belajar Nyaman dan Menyenangkan. Terjemahan Ary Nilandri. Bandung: Kaifa.

De Porter, B., \& M., H. (2004). Quantum Learning. Jakarta: Kaifa.

Depdiknas. (2005). Paket Pelatihan Lanjutan Untuk Sekolah dan Masyarakat. (Menciptakan

Masyarakat Peduli Pendidikan Anak Program Manajemen berbasis Sekolah). . Jakarta: Depdiknas-Dirjen Dikdasmen.

Hamalik, O. (2014). Kurikulum dan Pembelajaran. Jakarta: PT Bumi Aksara.

Hartati, L. (n.d.). Pengaruh Gaya Belajar Dan Sikap Mahasiswa Pada Pelajaran Matematika Terhadap Hasil Belajar Matematika. Jurnal Formatif. Vol 3 No 3 , 224-235.

Marpaung, Y. (2003). Pembelajaran Matematika yang Menyenangkan . Seminar Nasional Komperda Himpunan Matematika Indonesia Wilayah Jawa Tengah \& DIY. . Surakarta.

Putra, F., Atmojo, K., \& Sujadi, I. ( 2014). Eksperimentasi Model Pembelajaran Kooperatif Tipe TGT Berbantuan Software CABRI 3D Ditinjau Dari Gaya Belajar Siswa. Jurnal Elektronik Pembelajaran Matematika. Vol.2 No.8 , 816-827.

Ramlah, F. D. (2014). Pengaruh Gaya Belajar dan Keaktifan Siswa Terhadap Prestasi Belajar Matematika (Survey Pada SMP Negeri di Kecamatan Klari Kabupaten Karawang). Jurnal IImiah Solusi. Vol.1 No. 3 , 68-75.

Yulianti, E., Zulkardi, \& Siroj A, S. (2010). Pengembangan Alat Peraga Menggunakan Rangkaian Listrik Seri Parallel untuk Mengajarkan Logika Matematika di SMK Negeri 2 Palembang. Jurnal Pendidikan Matematika. Vol 4 No $1,1-8$. . 